\title{
Talon Cusp/Dens Evaginatus of Anterior Teeth: A Case Report of A Developmental Dental Anomaly
}

\author{
Maruthi Devi $\mathrm{K}^{1}$, Kiran $\mathrm{G}^{2}$, J yothsna $\mathrm{M}^{3}$
}

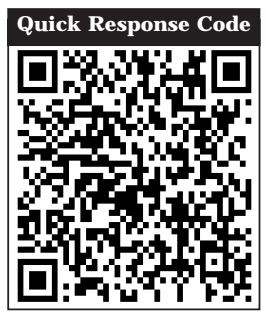

doi: $10.5866 / 2014.631629$

'Senior Lecturer

Dept. of Oral and Maxillofacial Pathology,

Meghana Institute of Dental Sciences,

Nizamabad, A.P, India

${ }^{2}$ Asst Professor

${ }^{3}$ Assoc Professor

Dept. of Oral and Maxillofacial Pathology,

Govt. Dental College \& Hospital,

Hyderabad, A.P, India

\section{Article Info:}

Received: April 11, 2014

Review Completed: May 13, 2014

Accepted: J une 10, 2014

Available Online: October, 2014 (www.nacd.in)

(C) NAD, 2014 - All rights reserved

\section{Email for correspondence:}

kmaruthidevi@gmail.com

\section{Introduction}

Dens evaginatus is one of the developmental anomalies affecting the shape of teeth having a tubercle like extra cusp either on lingual or occlusal surface of teeth. ${ }^{1}$ This anamoly was first reported on the lingual surface of a maxillary central incisor by Mitchell in 1892. ${ }^{2}$

As dens evaginatus of anterior tooth resembled the shape of an eagle's tal on it was termed as talons

\section{ABSTRACT:}

Developmental anomalies affecting the teeth are often seen in the oral cavity. Abnormalities in the physiological processes of tooth development lead to these anomolies. Tal on cusp or dens evaginatus of anterior tooth is one of the dental anomalies affecting the shape of a tooth, in which an accessory cusp like structure projects from the cingulam area or cementoenamel junction.

Key words: Talon cusp, Dens evaginatus, Lateral incisor 


\section{CASE REPORT:}

A female patient of 20 years old approached a private dental clinic with a complaint of malposed upper left tooth (Figure 1). On examination, 22 was buccally placed and revealed presence of one extra cusp on its lingual surface (Figure 2). The cusp extended from cingulum to $3 / 4^{\text {th }}$ of the crown length and has a talon like appearance. Radiographically the extra cusp or talon cusp appeared like a normal tooth consisting enamel, dentin and a horn of pulpal tissue extending into the cusp (Figure 3 ). Occlusal view and OPG also showed the presence of a talon cusp overlapping the lateral incisor (Figure 4). Her family history was negative. No other dental anomalies were observed. As the extra cusp caused occlusal interference, we planned for gradual reduction of the cusp in successive visits with fluoride application each time.

\section{DISCUSSION:}

Talon cusp apart from showing its structure resembling to an eagles talon, it can also appear like a pyramid or conical in shape. ${ }^{4,5}$ An extra cusp like structure on a tooth to be called as a tal on cusp, it should extend at least $1 \mathrm{~mm}$ or more beyond Cemento-Enamel J unction (CEJ) or half the distance from CEJ to the incisal edge. ${ }^{6}$

Prevalence of talon cusp has been found to be less than $1 \%$ of population. ${ }^{1}$ Review of the literature showed that the incidence of talon cusp in the permanent and primary dentition was $75 \%$ and 25 $\%$ respectively. It generally has a predilection for the maxilla. Most frequently involved teeth were maxillary central incisors followed by lateral incisors and the canines. It showed a male preponderance (65\%). Majority of the cases seen were unilateral, whereas $1 / 5^{\text {th }}$ of cases were bilateral..$^{7-9}$ The present case was a female patient with talon cusp on left maxillary lateral incisor.

Talon cusp may occur either alone or along with other anomalies like mesiodens, odontome, unerupted or impacted teeth, peg shaped maxillary incisors, dens invaginatus, cleft lip and disordered nasal alae, gemination, fusion and supernumerary teeth. ${ }^{4}$ 10-12 This patient did not showed any other dental anamoly apart from talon cusp. Generally a tooth with talon cusp is wider mesiodistally and thicker labio-lingually than other teeth. ${ }^{13}$ Tal on cusp is found to be more common in patients with syndromes like Rubinstein-Taybi syndrome, Mohr syndrome and Sturge-Weber syndrome. ${ }^{14}$

The precise aetiology of talon cusp is not wellknown, but it is suggested that a combination of genetic and environmental factors may play a vital role in its formation. It is considered to arise during the morpho-differentiation stage of tooth devel opment, as a result of out fol ding of the enamel organ or hyper productivity of the dental Iamina. Few studies have shown that altered endocrine function during morpho-differentiation may affect the size and shape of the tooth without impairing the function of ameloblasts and odontoblasts. This anomaly has been reported to be associated with parental consanguinity. ${ }^{3,13}$

Hattab et al classified talon cusps into 3 types based on the degree of cusp formation and its extension,

Type1 (Talon): where the additional cusp projects from the palatal surface of an anterior tooth and extends at least half the distance from the CEJ to the incisal edge.

Type 2 (semi talon): where the additional cusp is one $\mathrm{mm}$ or more in length but extends less than one half the distance from the CEJ to the incisal edge.

Type 3 (trace talon): which manifests an enlarged and prominent cingula., 6

Based on the above classification, the present case is of typel.

The clinical problems seen in patients with talon cusps comprise of stagnation of food, caries, periapical lesions, irritation of tongue during speech and mastication, other soft tissue irritation, breast feeding problems, compromised aesthetics, occlusal interference which may lead to accidental cusp fracture, displacement of the affected tooth, temporomandibular joint pain, and periodontal problems because of excessive occlusal force. ${ }^{6}$

Radiographically, a talon cusp appears similar to that of a normal tooth, presenting with radiopaque enamel and dentin with or without extension of 


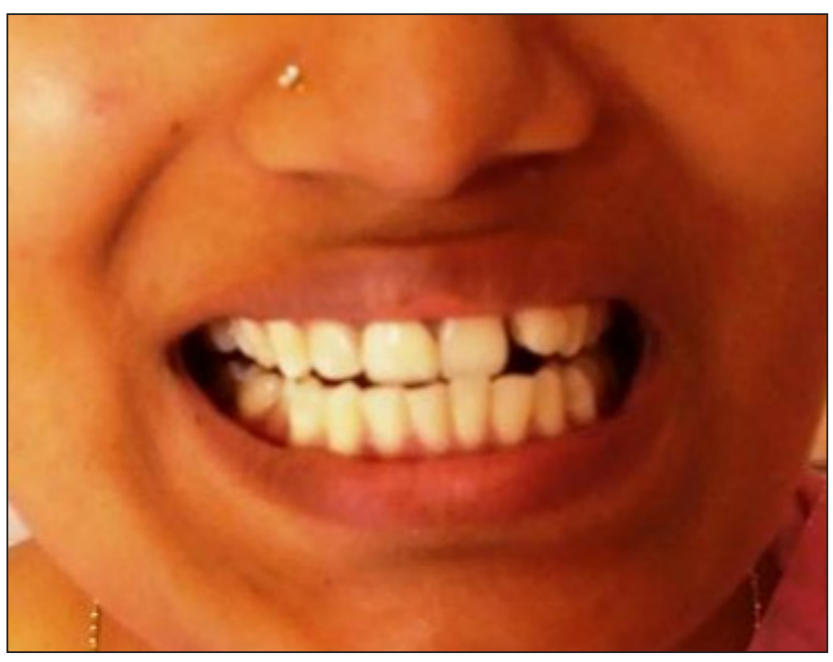

Figure 1: Extra-oral view showing malposed upper left tooth.

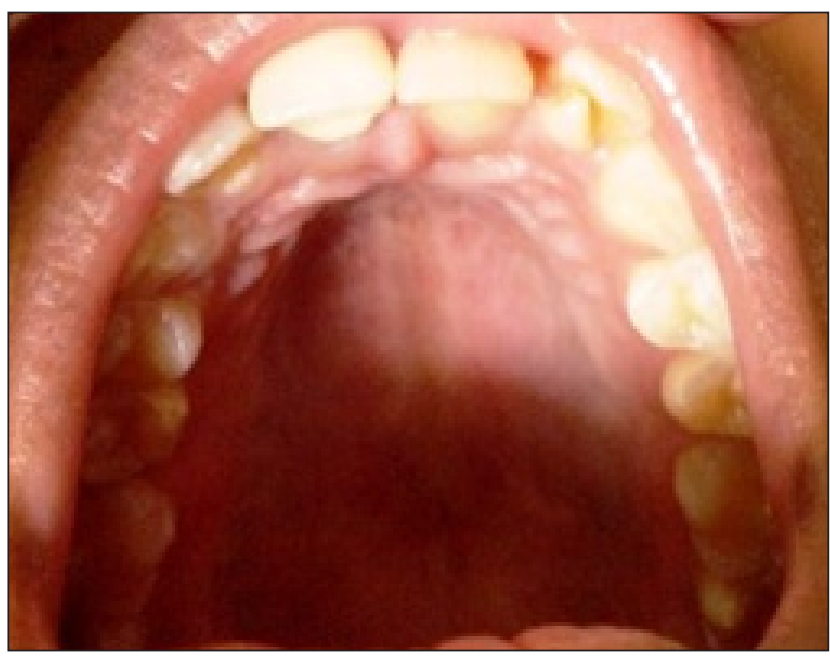

Figure 2: Intra-oral view reveals presence of one extra cusp on its lingual surface of 22.

pulpal tissues. It looks like a $\mathrm{V}$ shaped structure superimposed over the normal image of the crown. When the tooth is unerupted, a radiographic talon cusp may resemble mesiodens, compound odontoma, supernumerary tooth or a dens invaginatus, hence should be included in differential diagnosis. ${ }^{6}$

The complications of talon cusp are broadly categorized into aesthetic, diagnostic, functional, and pathological. A large talon cusp poses aesthetic problems. It might present diagnostic problems if it is unerupted and resembles a supernumerary tooth or a compound odontome and so result in

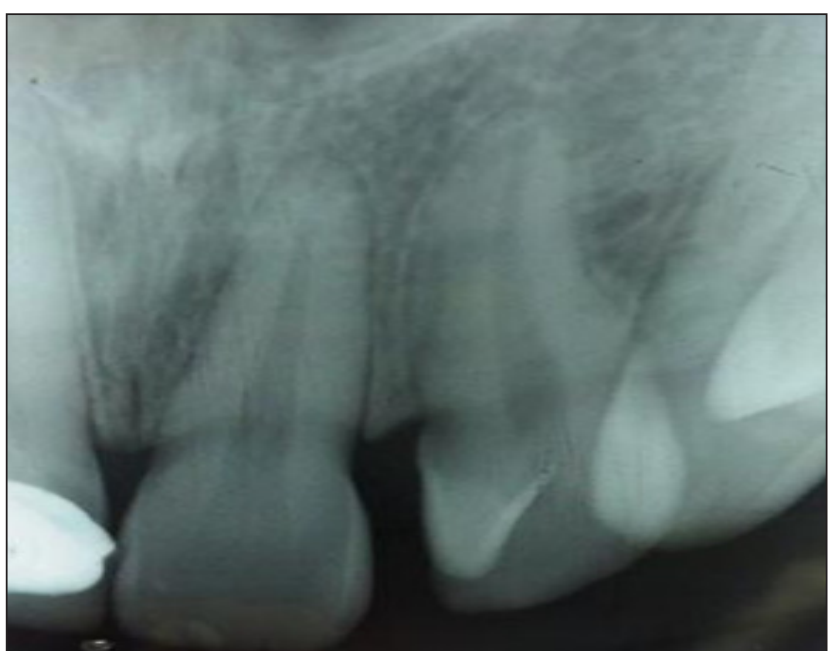

Figure 3: IOPA showing extra cusp or talon cusp consisting enamel, dentin and a horn of pulpal tissue extending into the cusp of 22.

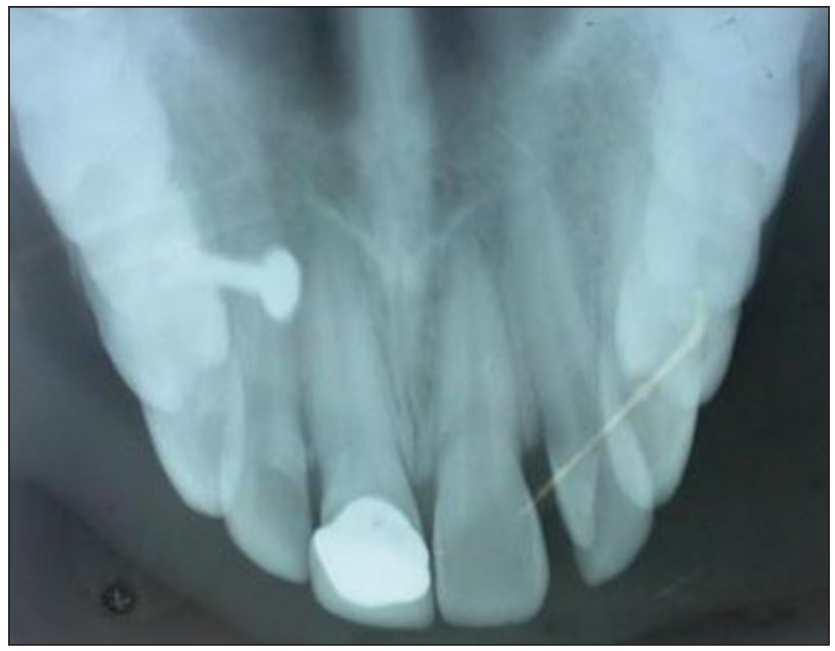

Figure 4: Occlusal view showing the presence of a talon cusp overlapping the lateral incisor (22).

unnecessary surgical procedures. Functional complications comprise of occlusal interference, trauma to the lip and tongue, speech problems and displacement of teeth. The deep grooves which join the cusp to the tooth may act as retentive areas for plaque and debris, develop into carious tooth and may consequently cause periapical pathology. Talon cusp may also cause minor problems such as speech disturbances, accidental cuspal fracture, tongue irritation and periodontal problems due to extreme occlusal forces. ${ }^{12}$ Our patient complained of occlusal interference and esthetic problems. 
Management of talon cusp depends on individual presentation and resulting complications. Small talon cusps generally are asymptomatic and hence need no treatment. Talon cusps with deep developmental grooves need simple prophylactic measures such as fissure sealing and composite resin restoration. If it causes occlusal interference, the bulk of the cusp should be gradually and periodically reduced followed by application of topical fluoride such as Duraphat or Acidulated Phosphate Fluoride (APF) gel in order to reduce sensitivity as well as to stimulate reparative dentine formation for pulp protection. In some cases with extreme occlusal problems, total reduction of the cusp should be carried out fol lowed by calcium hydroxide pul potomy or completely reduce the cusp, extirpate the pulp and root canal therapy is carried out. When talon cusp results in tooth displacement or mal-alignment of affected or opposing teeth orthodontic correction should be done. 3, 11, 15

\section{REFERENCES:}

1. Dankner E, Harari D, Rotstein I. Dens Evaginatus of anterior teeth: literature review and radiographic survey of 15000 teeth. Oral Surg Oral Med Oral Pathol Oral Radiol Endod 1996; 81:472-476.

2. Segura JJ, Jimenez Rubio A. Talon cusp affecting permanent maxillary lateral incisors in 2 family members. Oral Surg Oral Med Oral Pathol Oral Radiol Endod 1999; 88:90-92.

3. Gupta R, Thakur N, Thakur S, Gupta B, Gupta M. Talon cusp: A case Report with management Guide lines: Dent Hypothesis. 2013; 4:67-69.
4. Mupparapu M, Singer SR, Goodchild J H. Dens evaginatus and dens invaginatus in a maxillary lateral incisor: Report of a rare occurrence and review of literature. Aus Dent J 2004; 49(4):201-203.

5. Hattab FN, Yassin OM. Bilateral talon cusps on primary central incisors: A case report. Int J Paediatr Dent 1996; 6:191-195.

6. Hamasha, Safadi. Prevalence of Talon cusp in J ordanian Permanent Teeth: A radiographic Study. BMC Oral Health 2010; 6:1-5.

7. Hattab FN, Yassin OM, al Nimri KS. Talon cusp in permanent dentition associated with other dental anomalies: review of literature and reports of seven cases. ASDC J Dent Child 1996; 63:368-376.

8. Chen RJ, Chen HS. Talon cusp in primary dentition. Oral Surg Oral Med Oral Pathol 1986; 62:67-72.

9. Rao et al. Talon Cusps in Mandibular Incisors: An Unusual Presentation in a Child Patient. J ODD 2011; 5(1):37-39.

10. Hattab FN, Hazzaa AM. An Unusual Case of Talon Cusp on Geminated Tooth. J Can Dent Assoc 2001; 67:263-266.

11. Sener S, Unlu N, Basciftci FA, Bozdag G. Bilateral geminated teeth with talon cusps: A case report. Eur J Dent 2012; 6:440-445.

12. Thakur S, Gupta R, Thakur NS, Gupta M. Facial Talon Cusp on Permanent Maxillary Canine: A Rare Dental Anomaly. Eur J Gen Dent 2013; 3:324-327.

13. Ozcelika B, Atilaa B. Bilateral Palatal Talon Cusps on Permanent Maxillary Lateral Incisors: A Case Report. Eur J Dent 2011; 5:113-116.

14. Tulunoglu O, Cankala DU, Ozedmir RC. Talon's cusp: report of four unusual cases. J Ind Soc Pedo Prev Dent 2007; 25(1):52-55.

15. Hattab FN, Yassin OM, al-Nimri KS. Talon cusp-clinical significance and management: case reports. Quintessence Int 1995; 26:115-120.

\section{Gain quick access to our journal online View our journal at} www.nacd.in 